\title{
16. まちづくり市民活動団体の役割構造の分析手法開発に向けた基礎研究
}

\author{
Fundamental study on development of the analysis method for role structure on community action groups
}

\author{
筁谷 祐介*・椎野 亜紀夫**・斉藤 雅也***・柿山 浩一郎***・中原 宏*** \\ Yusuke Yabutani*, Akio Shiino**, Masaya Saito***, Koichiro Kakiyama*** and Hiroshi Nakahara***
}

\begin{abstract}
This paper aimed at developing the methodology of identifying each member's role in specified community action groups, using the quantitative analysis comparing with two different types of community action groups. It is useful for community designer to support community action groups not only by identifying their issue, but also by proposing a direction to solve the problem. Corresponding analysis and cluster analysis were applied, targeting each member of two community action groups. As a result, a certain amount of each member's role in groups and his/her characteristic was specified visible in scatter diagrams or radar charts. However, it is a subject for future analysis to improve the methodology of specifying lack of a presence of independent-minded planner in groups.
\end{abstract}

Keywords: community action group, community activity, role, community design, management 市民活動団体，まちづくり，役割，コミュニティデザイン，マネジメント

\section{1.はじめに}

町内会や自治会などの地縁型団体は、伝統的に地域にお ける公共サービスを総合的に担ってきた。しかし近年、地 域で助け合うという生活文化を持たない若年世代が地域の 世帯構成の中心になりつつあることや、住民の連携感の希 薄化に伴い、加入率の低下や担い手不足、活動の停滞等の 問題が生じつつある1)。こうした社会の変化のなかで、今 後は多主体がパートナーシップの関係を構築し、協働して 地域社会を総合的にマネジメントしていくことが求められ ている2。その中で特定のテーマを掲げてまちづくり (1) を 実践寸る市民活動団体（以下、まちづくり団体 (2) ）は「住 民自治」(3) の概念に基づき、まちづくりを主導することが 期待されている。すなわち、まちづくりのビジョンを共有 しつつ、個別課題への対応や多主体の連携による相乗作用 を生み出す役割を担い 2)、他のまちづくり団体や地縁型団 体、行政、企業等の多主体と連携しながら多椂化する地域 課題の解決に取り組むことが期待されている。近年では、 外部の専門家が介入し、人を集め、まちづくり団体の形成 を促すことで地域課題解決に取り組むコミュニティデザイ ン3) が注目されており、今後は持続性のあるまちづくり団 体をいかに形成し、マネジメントしていくかが重要な課題 である。

しかしながら、これまで都市計画の分野では、まちづく り団体のマネジメント技術について十分研究がされてきた とは言いがたい 4) その理由として、非営利団体であるま ちづくり団体はしばしば定性的な目標を掲げるため、その 効果の測定は困難であり、そのため実践においては目標達 成に向けた活動自体が評価され、その効果を具体的に指標 で測定することや、合理性と効率性を重視したマネジメン 卜上の仕組みを構築することは軽視される傾向があったこ
とが挙げられる5)。

しかしながら、まちづくり団体の活動では多くの場合、 その成果が現れるには多大な時間を要し、活動の意義を 徐々に見失っていくケースなど、持続性に対する課題が指 摘されており 6、継続的な活動を実現させるための手法の 確立に向けた理論構築、ならびにこれを応用した効果的、 効率的なマネジメント技術の開発が必要である。

団体におけるマネジメントの対象として、人材、設備、 財政、情報が挙げられる 7)。内閣府の調査報告書では、ま ちづくり団体が継続的に活動するための人材マネジメント の重要性を指摘しており 8 、持続的な活動を行っていくた めには地域の様々な住民を巻き込み、そして構成員を最大 限に活用寸る効果的な人材マネジメントが重要であると考 えられる。

経営学の分野で支持されているオ八イオ研究では、リー ダーの行動として、人間関係を尊重する「配慮」と、構成 員に役割を示寸「構造づくり」の 2 次元を抽出し、この 2 つが高いリーダーの行動が構成員の仕事達成度と満足度を 高めるとしている9 のれ。団体のマネジメントにおいて 構成員の人間関係と役割を考慮することの重要性を示して おり、この 2 つを分析することで効果的なマネジメント技 術を開発できると考えられる。

人間関係を分析する手法としてはネットワーク分析 (4) がある。この分析手法は、まちづくり団体の構成員の知識 の伝達・共有の流れや団体の中心性を明らかにした研究 10) や、過疎・高齢地域の集団構成を包括的に把握した研究 $\left.{ }^{11}\right)$ 等、まちづくり団体の人間関係を分析する手法として用い られている。一方、役割を分析寸る手法研究としては、ま ちづくり団体の会議における発話者の発話行為の割合（夕 ーン分析）と発言内容（コンテクスト分析）からリーダー

* 正会員 富山大学芸術文化学部 (University of Toyama)

** 正会員 札幌市立大学デザイン学部（Sapporo City University）

*** 非会員 札幌市立大学デザイン学部（Sapporo City University） 
の機能評価を行う手法研究 12) があるが、これは会議という 構成員が発話寸る場に限定された役割の分析手法であり、 普段の活動においてどのような役割分担がされているかを 解明する手法はほとんじない。その理由は、前述したよう にこれまでまちづくり団体のマネジメント技術についてま だ十分な研究蓄積がないからであると考えられる。

山崎はコミュニティデザインの要点の1つに、多様な居 住歴、居住地、年齢、性別、職業からなる構成員を集める ことを心がけることを挙げており 13)、構成員の多様さがま ちづくり団体の形成において重要であることを示している。 倉原は、多様な構成員からなるまちづくり団体は、構成員 がそれぞれの知識・技術・経験を適宜柔軟に生かしながら 役割を担うことで活動を促進すると指摘しており 14)、構成 員が各能力を生かした役割を担うことにより効果的な団体 マネジメントが可能となり活動も活発化寸ると考えられる。

つまり、まちづくり団体の人材マネジメントにおいて構 成員の役割分担が重要な課題の一つであり、団体の効果的 なマネジメントにはその役割分担の現状把握と課題抽出が 必要となる。そのためには第一段階として、団体を成立さ せる構成員とその役割分担の関係（以下、役割構造）を分 析する手法を開発すること、第二段階として、その手法を 用いて数多くの団体を分析することで効果的にマネジメン トするための役割構造モデルを明らかにすることが必要で ある。それにより、マネジメントの対象とする団体と役割 構造モデルとを比較分析し、その団体の特徽と課題を特定 することで、マネジメントの方向性を提示することができ ると考えられる。団体の特徵と課題についてはヒアリング 調査によって定性的に把握する方法も考えられるが、比較 分析寸るためには定量的に分かりやすく役割構造を視覚化 することが求められる。

そこで本研究は先に挙げた第一段階として、(1)数理的手 法を用いてまちづくり団体の役割構造を視覚化し、(2)団体 を比較分析することによって各団体の特徴と課題を明らか にできるか検証する。以上により、まちづくり団体の役割 構造を解明寸るための手法開発を本研究の目的とする。本 研究は、専門家によるまちづくり団体への支援として、役 割構造を視覚化することにより、団体の課題特定とマネジ メントの方向性を提示寸ることができる点に意義があり、 数量的に団体の役割構造を分析し視覚化する点に独自性が ある。

\section{2. 研究方法}

\section{1. 研究対象}

「結いプロジェクト」と「大子町屋台研究会」の 2 つの まちづくり団体を研究対象とした。これらの団体の選定理 由としては、(1)設立から 5 年以上が経過した団体で構成員 同士が互いに団体内での役割を認識しているため確度の高 いデータが得られると期待でき、(2)設立時期が近く同程度 の成熟度であることが想定できる団体で比較対象として適 当だからである。対象は 2 団体と限定的であるが、各団体
表 1 アンケート調査の項目

\begin{tabular}{c|l|l|}
\hline \multirow{3}{*}{$\begin{array}{c}\text { アンケート } \\
\text { 項目 }\end{array}$} & 回答者の属性 & 性別、年代、職業、所属グループ数、居住歴※ \\
\cline { 2 - 3 } & まちづくり団体への参加 & 参加時期、参加のモチベーション \\
\cline { 2 - 3 } & 評価 & $\begin{array}{l}\text { まちづくり団体のまちへへの貢献度 } \\
\text { 構成員のまちづくり団体への貢献度 }\end{array}$ \\
\hline \multirow{2}{*}{ ※居住歴より居住地域数を把握する }
\end{tabular}

表 2 構成員の性格特性

\begin{tabular}{|l|l|}
\hline CP (Critical Parent) & リーダー性が高い \\
\hline NP (Nurturing Parent) & 支持性、共感性が高い \\
\hline A (Adult) & 合理性が高い \\
\hline FC (Free Child) & 創造性が高い \\
\hline AC (Adapted Child) & 協調性が高い \\
\hline
\end{tabular}

の組織形態、設立時期、規模が概ね同じ（表 4) であるため 役割分担について比較しやすく、かつ 3 章で示すように役 割分担の異なる特徵を持つ 2 団体を選定したことで比較分 析が可能となり、分析手法開発に向けた検証の第一段階と して妥当であると判断した。

\section{2. 研究手順}

（1）まず、ヒアリング調査によって各まちづくり団体の概 要と役割分担の特徵と課題を定性的に把握する。

(2) 次に、アンケート調査等によって各団体の構成員の特 性と役割を把握し、役割に関するデータを用いてコレ スポンデンス分析とクラスター分析を行い、布置図と レーダーチャートによって各団体の役割構造を視覚化 する。

（3）（2）の結果を用いて構成員の特性と役割の関係を分析・ 考察する。

（4）最後に、（1）で定性的に明らかにした各団体の役割分担 における特徵と課題を、2 団体の分析結果の比較分析 から定量的に明らかにできるか検証する。

\section{3. 構成員の特性調査}

(1) アンケート調査

構成員の特性を把握するために、下記a）～c) に示す項目 のアンケート調查票を作成した（表 1)。

a）回答者の属性

前述の通り、多様な居住歴、居住地、年齢、性別、職業 からなる団体の形成が重要であるため、これらの属性項目 を設定した。

b）まちづくり団体への参加

饗庭らによると、まちづくりに参加している主体の多く は、マズローの欲求段層論のうちの「所属と愛情の欲求、

「尊重の欲求」「自己実現の欲求」の3 つの欲求に基づい ている(5)。そこで参加のモチベーションを把握するために、 予めその 3 つの欲求に分類した 12 の選択肢 ${ }^{(6)}$ と、その他 の自由記述闌を設定した。また、参加時期についての選択 肢も設けた。

c) 評価

構成員がまちづくり団体の活動成果を評価するための 「まちづくり団体のまちへの貢献度」の項目と、構成員自 身の働きを自己評価するための「構成員のまちづくり団体 への貢献度」の項目を設け、100 点満点の自己採点によっ て回答を得ることとした。 
（2）「新版東大式エゴグラム II （TEG II）」15)

構成員の性格特性を把握するために、性格特性を分析す るために広く使われているエゴグラムを採用した。本研究 で使用した「新版東大式エゴグラムIII (TEG II)」は、53の 質問に回答寸ることで、5 つの性格特性（CP、NP、A、FC、 AC）（表 2）が点数化される。その性格特性のうち、点数が 最大值であるものを構成員の特徽的な性格特性とした。

\section{4. 構成員の役割調査}

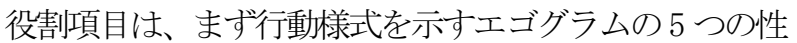
格特性を団体における役割として適用できると考え、これ に対応する 5 項目を設定した。次に、先に挙げた 5 項目以 外の役割について文献 14 を参照し 3 項目を設定した。さら に、実際に活動している構成員が普段の活動の中で把握す る役割もあると考え、今回の研究対象の 2 団体に所属する 構成員 10 名 (各団体の代表者または事務局による紹介)を 対象としたヒアリング調査によって 2 項目を抽出した。以 上、10 の役割項目を設定した (7)。また、役割項目とは別に、 全構成員の中で特に活躍が目立つと考えられている各団体 のキーパーソンを選ぶ 1 項目を設定した（表 3 )。

これらの項目をどの構成員が担っているか、各構成員が 自分以外のすべての構成員を対象に相互に投票寸る形式の 調查票 ${ }^{(8)}$ を作成した。構成員による投票数のばらつきがな いよう 1 項目につき 5 名まで投票できるものとした。すな わち、役割の構造を客観的に把握できる手法として、す心゙ ての構成員を対象とした相互評価方式を採用した。

\section{5. 調査実施方法}

（1）各団体の概要や役割分担の特徵と課題を把握寸るため に、各団体の代表者を含む構成員に対しヒアリング調 查を実施した。

（2）2つの団体の事務局に調查協力を依頼し承諾を得て、 各団体の名簿に記載されているすべての構成員に対し、 アンケート調査票、TEG II、構成員の役割調査票、依頼 文を配付してもらった。依頼文では、回答者の匿名性 を確保して研究を進めることを説明し、正確な回答を 得ることに配慮した。調查票は構成員からの郵送によ り回収した。

\section{3. 定性的調査の結果}

本研究で対象とした 2 団体の概要、役割分担の特徵、課 題について以下に述べる。

\section{1.「結いプロジェクト」の概要と役割分担の特徵と課題}

「結いプロジェクト」は茨城県結城市で活動するまちづ くり団体（任意団体）で、2 名の地域を盛り上げたいと考 える若者が声がけして仲間を集め、2010 年に発足した。見 世蔵等のまちの空間資源を活用し、結い市」というクラフ 卜市や「結いのおと」といらまちなか音楽イベントの企画・ 運営を通して、まちの活性化を目指している。最初は見世 蔵の所有者と 1 軒ずつイベントで使用できるよう交渉し、 2010 年から「結い市」を、2013 年から「結いのおと」を毎 年開催している。2016 年からは商工会議所の創業支援事業

\section{表 3 役割に関わる調査項目}

\begin{tabular}{|c|c|c|c|}
\hline 調査内容 & 役割の相互評価項目（䛦当またはは非玟当） & 省略表記 & 参照元 \\
\hline \multirow{3}{*}{$\begin{array}{l}\text { まちづくり団体 } \\
\text { における構成員 } \\
\text { の役割 }\end{array}$} & $\begin{array}{l}\text { リーダーシップを発揮している } \\
\text { 相談に乗ってくれた、助けてくれる } \\
\text { 話を整理したり、問題点を指摘してくれる } \\
\text { アイデアを出してくれる } \\
\text { いつも協力的である }\end{array}$ & $\begin{array}{l}\text { リーダー } \\
\text { 相談役 } \\
\text { 話を整理 } \\
\text { アイデア } \\
\text { 㙝力的 } \\
\end{array}$ & $\begin{array}{l}\text { エゴグ } \\
\text { ラム }\end{array}$ \\
\hline & $\begin{array}{l}\text { 活動を発信、情報を収集してくれる } \\
\text { 様々な調整や裏方仕事をしてくれる } \\
\text { 知識や技术を提供してくれる }\end{array}$ & $\begin{array}{l}\text { 情報発信 } \\
\text { 調整役 } \\
\text { 知識の提供 }\end{array}$ & 文献 14) \\
\hline & $\begin{array}{l}\text { 場の雲囲気を良くしてくれる } \\
\text { 活動のための場やものを提供してくれる }\end{array}$ & $\begin{array}{l}\text { 場の雾囲気 } \\
\text { 場・モノの提供 }\end{array}$ & $\begin{array}{l}\text { ヒアリン } \\
\text { グ調査 }\end{array}$ \\
\hline キーパーソン & \multicolumn{3}{|l|}{ 特に活躍が目立つメンバーである } \\
\hline
\end{tabular}

表 4 各団体の概要と役割分担の特徵と課題

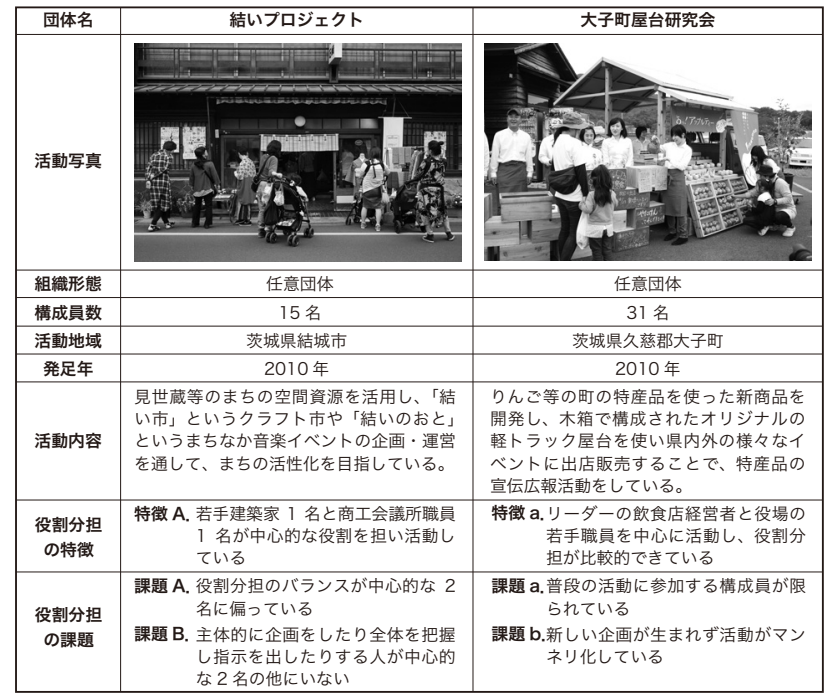

の企画を担当している。現在は月 2 回程度の定例会と年 4 回程度のイベントを実施している。イベントの規模と認知 度は年々拡大し、2016 年に行われた「結い市」では参加者 が 2 日間で約 3 万人にも上った。最近は様々なメディアで も取り上げられ、注目を集めている。発足当初は助成金を 得ていたが、現在はイベント収入によって運営している。 若手建築家 1 名と商工会議所職員 1 名が中心的な役割を担 い活動している（特徴 A とする）が、役割分担のバランス がその 2 名に偏っており (課題 A とする)、主体的に企画を したり全体を把握し指示を出したりする人が他にいない (課題B とする) ことが課題である（表 4)。

\section{2.「大子町屋台研究会」の概要と役割分担の特徵と課題}

「大子町屋台研究会」は茨城県久慈郡大子町で活動する まちづくり団体（任意団体）で、大子町から筑波大学への 2 年間の委託研究の中で、大学と大子町が共同で事務局を 担い、2010 年に発足した。りんご等の町の特産品を使った 新商品を開発し、木箱で構成されたオリジナルの軽トラッ ク屋台を使い県内外の様々なイベントに出店販売すること で、特産品の宣伝広報活動をしている。構成員は役場職員、 飲食店経営者、木工職人、農家、学生等、役場加多方面 に声かけして集めた。研究期間終了後も数名の役場職員と 学生は構成員として自主的に参加している。主な活動は月 1 回の定例会と年に $4 、 5$ 回のイベント出店である。研究期 間終了後も大子町からの助成金により運営していたが、 
2013 年からは売上による自主運営をしている。これまでの 成果の一つとして、特産のりんごとお茶を使って開発した アップルティーが町内のカフェで提供されている。リーダ 一の飲食店経営者と役場の若手職員を中心に活動し、役割 分担が比較的できている（特徵 a とする）が、普段の活動 に参加する構成員が限られ (課題a とする)、また新しい企 画が生まれず活動がマンネリ化していること（課題b とす る）が課題である（表 4 ）。

\section{4. 「結いプロジェクト」の役割構造分析 \\ 4.1. 構成員の特性}

対象団体の構成員 15 名に調查票を配付し 13 名から回答 を得た（回収率 $86.7 \%$ )。表 5 (№.の欠番は回答なし) は アンケート調査と TEG II の結果である。

\section{2. 構成員の役割による類型の視覚化}

構成員の役割調査の得票数の集計結果を用いてコレスポ ンデンス分析 ${ }^{(9)}$ を行った。第2 次元までを採用し、累積寄 与率 $53.5 \%$ （第 1 軸 $34.4 \%$ 第 2 軸 $19.1 \%$ ） という結果 を得た。構成員（表 5 の No. 1〜15）と 10 項目の役割をプ ロットした布置図を作成した (図 1)。布置図の縦軸より左 側には「様々な調整や裏方仕事をしてくれる」、右側には「知 識・技術を提供してくれる」が布置されていることから横 軸はく労働の提供一資産の提供＞軸とした。また横軸より上 側には「様々な調整や裏方仕事をしてくれる」、下側には「話 を整理したり、問題点を指摘してくれる」「アイデアを出し てくれる」「知識や技術を提供してくれる」がプロットされ ていることから、縦軸はく行動性一思考性＞軸とした。

次に、クラスター分析 (ウォード法) を用いて構成員を 5 つに類型化した (図 2$)^{(10)}$ 。類型ごとに図 1 の布置図上で 囲い、構成員の役割の得票数を平均化したものをレーダー チャート（図 3）で表し、各類型を(1)オールマイティなリ ーダー (2 名)、(2)情報発信をする知識・技術・アイデアの 提供者 (3 名)、(3)協力的な裏方調整役 (3 名)、(4)知識・技 術の提供者（2 名）、(5)ムードメーカー（5 名）とした。

図 1 の布置図を見ると、類型(1)原点から少し上に位置 し、その付近に「リーダーシップを発揮している」「相談に 乗ってくれたり、助けてくれる」等の多くの役割が密集し ている。また、図3 のレーダーチャート(1)みると、ほと んどすべての役割を類型(1)が担っていることが分かる。そ れに対し、類型(2)、(3)、(4)は原点から少し離れたところに 位置し、類型(2は「活動を発信、情報を収集してくれる」

「知識・技術を提供してくれる」「アイデアを出してくれる」、 類型(3は「様々な調整や裏方仕事をしてくれる」「いらも協 力的である」、類型(4)は「知識・技術を提供してくれる」と いう役割に特化している。類型(5はレーダーチャートより

「場の雰囲気を良くしてくれる」という役割に特化してい るが、布置図で様々な位置にプロットされている。キーパ ーソンは類型(1)、(2)、(3)に集中している。

\section{3. 構成員の特性と役割の関係}

構成員の特性を表す項目別に布置図を作成した（図 4)。
性別を見ると、女性はすべてく行動性一思考性＞軸の下側に 集中し、思考性の高、役割を担う傾向が見られる。モチ心゙ ーションに関しては、類型11は2 名全員が「自己実現の欲 求」、類型(3は 3 名全員が「所属と愛情の欲求」という共通 点が見られた。性格特性に関しては、類型ごとに共通点は 見られなかったが、2.3.で設定したエゴグラムの性格特性 に対応する役割のうち、3つの役割（「相談に乗ってくれた り、助けてくれる」「話を整理したり、問題点を指摘してく れる」「アイデアを出してくれる」）の近くに、その性格特 性（NP、A、FC）の構成員がプロットされていることから、 一部の構成員は性格特性が役割に影響していることが推察 される。年代、所属グループ数、居住地域数については、 役割との関係は見られなかった。

\section{4. 「結いプロジェクト」の役割構造の考察}

類型(1) 2 名は自己実現のために多くの役割を率先して 引き受ける行動性の高いリーダーである。これまでの居住 地域数も少なく、まちへの強い想いが原動力であると推察 できる。類型(2) 3 名はデザイン、web 等の専門職であり、 情報発信やアイデア・知識・技術を提供している。イベン トの企画運営を行うこの団体において、ブランディングや チラシ作成等の専門性を生かした重要な役割を担っている と推察できる。類型(3)裏方調整役は、他の構成員との活 動が楽しいという共通の参加モチベーションを持つ。類型 (4)は知識・技術の提供者、類型(5)は場の雾囲気を良くする 構成員であるが、構成員の共通の特徴は見られない。類型 (1)、(2)、(3)の活躍が特に目立ち、重要な役割を担っている と推察できるが、他の構成員も場の雰囲気を良くする等、 団体が円滑に活動するための役割を担っている。

\section{5.「大子町屋台研究会」の役割構造分析 \\ 5.1. 構成員の特性}

対象団体の構成員 31 名に調査票を配付し 21 名から回答 を得た（回収率 $67.7 \%$ )。表6（№.の欠番は回答なし）は アンケート調査と TEG II 結果である。

\section{2. 構成員の役割による類型の視覚化}

構成員の役割調査の得票数の集計結果を用いて、コレス ポンデンス分析を行った。第2 次元までを採用し、累積寄 与率 $57.0 \%$ （第 1 軸 $32.8 \%$ 十第 2 軸 $24.2 \%$ ） という結果 を得た。構成員（表 6 の No. 16〜46, 図 5 の欠番は得票数 ０）と 10 項目の役割をプロットした布置図を作成した (図 5)。布置図の縦軸より左側には「様々な調整や裏方仕事を してくれる」、右側には「知識・技術を提供してくれる」「活 動のための場やものを提供してくれる」という役割がプロ ットされていることから、横軸はく労働の提供-資産の提供 >軸とした。また横軸より上側には「様々な調整や裏方仕 事をしてくれる」、下側には「話を整理したり、問題点を指 摘してくれる」「アイデアを出してくれる」「知識や技術を 提供してくれる」がプロットされていることから、縦軸は <行動性一思考性>軸とした。

次に、クラスター分析（ウォード法）を用いて構成員を 
6 つに類型化し (図 6) ${ }^{(10)}$ 、類型ごとに図 5 の布置図上で囲 った。類型ごとに構成員の役割の得票数を平均化したもの をレーダーチャート（図 7) で表し、各類型を(1)情報発信・ 雾囲気を良くするリーダー (3 名)、(2)協力的な知識・技術・ アイデアの提供者（1名）、(3)協力的な裏方調整役（5名）、

\section{表 5 「結いプロジェクト」の構成員の特性}

\begin{tabular}{|c|c|c|c|c|c|c|c|c|c|c|}
\hline No. & 性 & \begin{tabular}{|l|} 
年 \\
代
\end{tabular} & 職業 & \begin{tabular}{|c|} 
所属 \\
グルーブ数
\end{tabular} & $\begin{array}{l}\text { 居住 } \\
\text { 地域数 }\end{array}$ & 参加年度 & $\begin{array}{c}\text { 参加の } \\
\text { モチーション }\end{array}$ & $\begin{array}{l}\text { ゲルーフ } \\
\text { 貢献度 }\end{array}$ & $\begin{array}{l}\text { 自身の } \\
\text { 貢献度 }\end{array}$ & エジグムム \\
\hline 1 & 男 & 30 & 会社員 & 3 & 1 & 2012 & 所属と愛情の欲求 & 80 & 70 & A \\
\hline 2 & 男 & 30 & 団体職員 (一般事務) & 1 & 1 & 2010 & 自己実現の欲求 & 100 & 98 & $\mathrm{FC}$ \\
\hline 3 & 男 & 20 & 自営業 Web関連 & 2 & 3 & 2012 & 自己実現の欲求 & 70 & 50 & A \\
\hline 4 & 女 & 20 & 会社員 & 1 & 3 & 2013 & 所属と愛情の欲求 & 30 & 30 & FC \\
\hline 5 & 女 & 30 & 会社員 & 2 & 1 & 2010 & 尊重の欲求 & 85 & 60 & A \\
\hline 6 & 男 & 30 & 会社員 & 1 & 4 & 2013 & 所属と愛情の欲求 & 70 & 30 & FC \\
\hline 7 & 男 & 30 & 設計事務所 & 2 & 1 & 2010 & 自己実現の欲求 & 80 & 80 & $\mathrm{NP}$ \\
\hline 8 & 男 & 30 & 会社員 & 4 & 5 & 2011 & 所属と愛情の欲求 & 90 & 70 & $\mathrm{NP}$ \\
\hline 9 & 女 & 30 & ブランドディレクター & 2 & 2 & 2012 & 尊重の欲求 & 100 & 70 & A, CP \\
\hline 10 & 男 & 30 & 看護師 & 4 & 5 & 2012 & 所属と愛情の欲求 & 99 & 80 & FC \\
\hline 11 & 男 & 30 & デザイナー & 5 & 5 & 2010 & 自己実現の欲求 & & & $A C$ \\
\hline 13 & 男 & 20 & 公務員 & 4 & 2 & 2010 & 自己実現の欲求 & 95 & 60 & $\mathrm{NP}$ \\
\hline 15 & 女 & 20 & 学生 & 10 & 3 & 2011 & 所属と愛情の欲求 & 75 & 15 & $\mathrm{NP}$ \\
\hline 平均 & & 26.9 & & 3.2 & 2.8 & 2011.2 & & 81.2 & 59.4 & \\
\hline 標準 & & 4.6 & & 2.3 & 1.5 & 1.1 & & 18.8 & 23.2 & \\
\hline
\end{tabular}

※CP (Critical Parent) : リーダー性 NP (Nurturing Parent) : 支援性 A(Adult) : 合理性
FC (Free Child) : 創造性 AC (Adapted Child) : 協調性

※表の空白箅所は、無回答

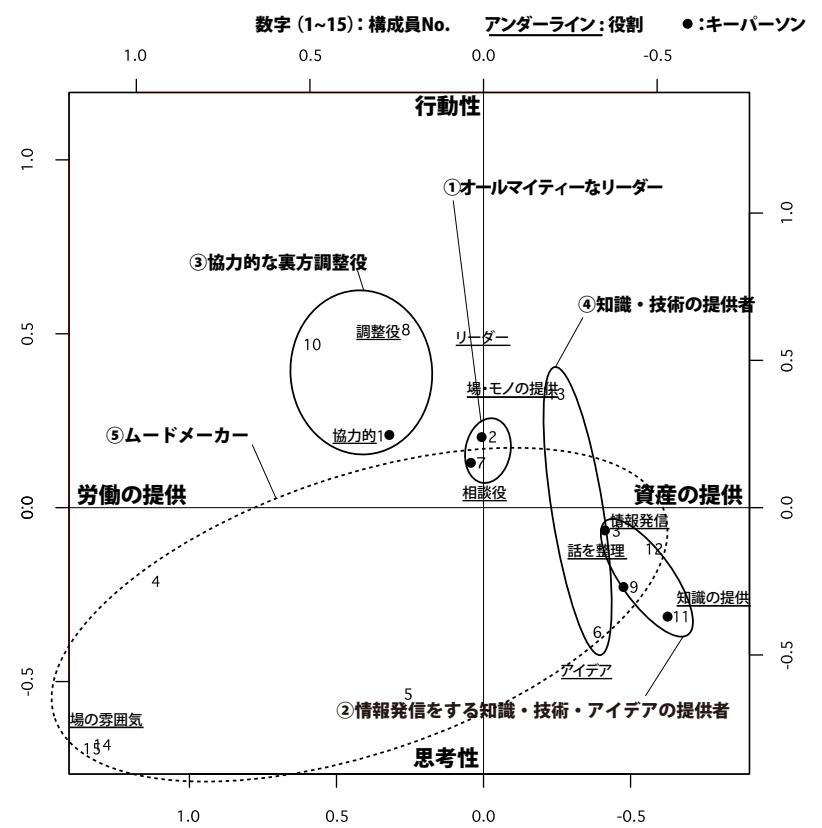

図 1 「結いプロジェクト」の構成員・役割同時布置図

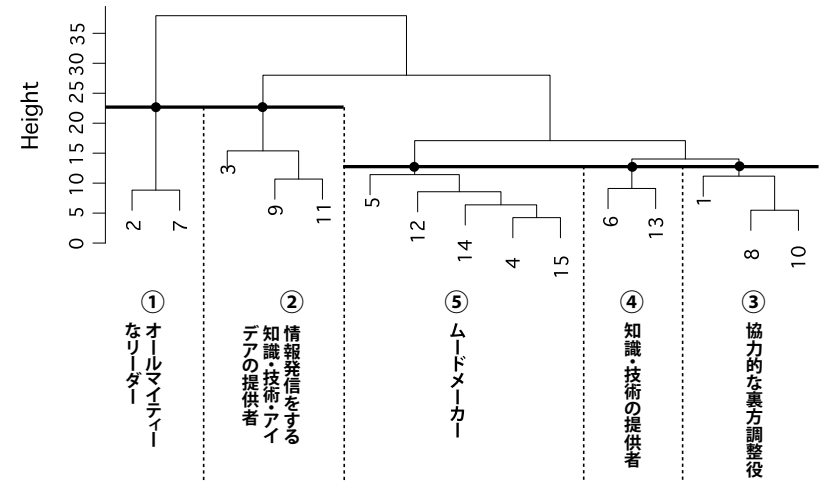

図 2 「結いプロジェクト」の構成員のクラスター構造
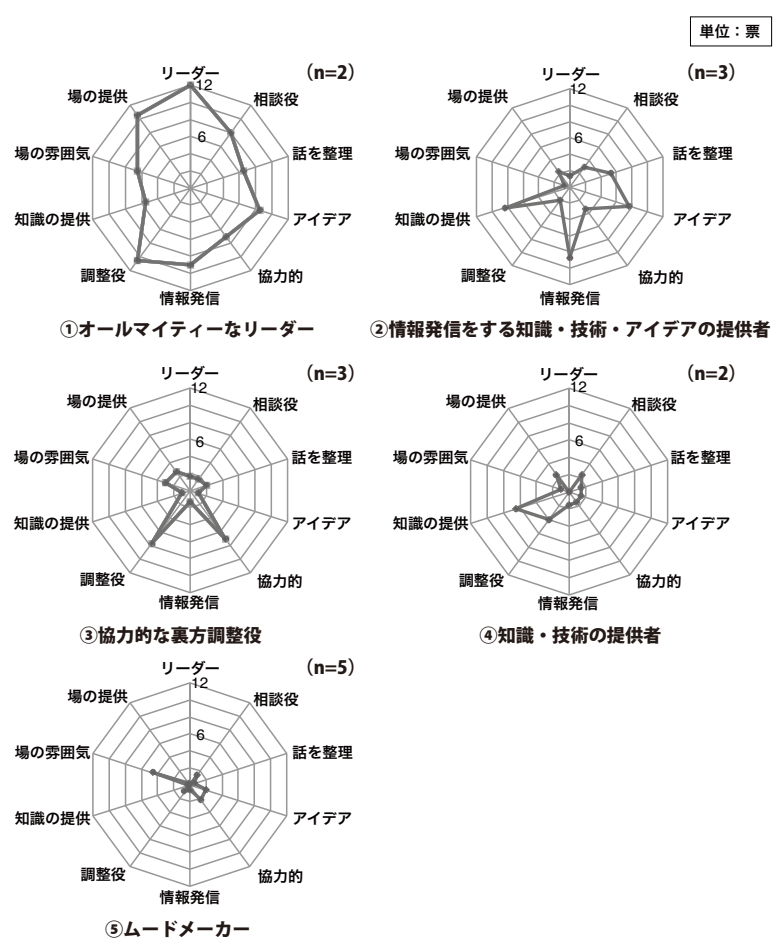

図 3 「結いプロジェクト」類型別役割レーダーチャート
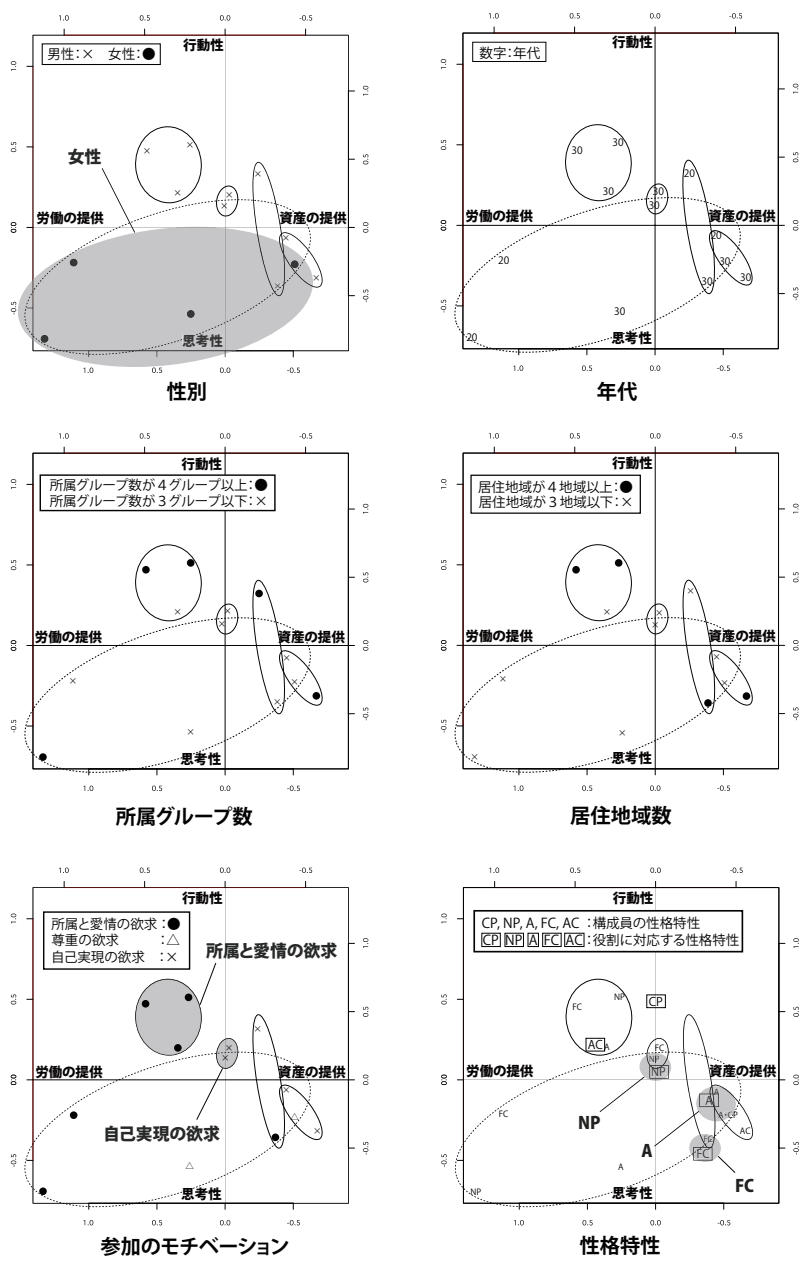

図4「結いプロジェクト」の特性と役割の関係分析図 
表 6 「大子町屋台研究会」の構成員の特性

\begin{tabular}{|c|c|c|c|c|c|c|c|c|c|c|}
\hline No. & 性 & $\begin{array}{l}\text { 年 } \\
\text { 代 }\end{array}$ & 職業 & $\mid$ & $\mid \begin{array}{l}\text { 居住 } \\
\text { 地域数 }\end{array}$ & 参加年度 & $\begin{array}{c}\text { 参加の } \\
\text { モチベーション }\end{array}$ & $\begin{array}{l}\text { 卢ルーフ } \\
\text { 貢献度 }\end{array}$ & \begin{tabular}{|l|} 
自身の \\
貢勃度
\end{tabular} & エゴグラム \\
\hline 16 & 男 & 40 & 地方公務員 & 7 & 2 & 2010 & 自己実現の欲求 & 60 & 80 & $A C$ \\
\hline 17 & 男 & 60 & & 6 & 3 & 2011 & 自己実現の欲求 & 10 & 100 & $\mathrm{CP}$ \\
\hline 20 & 男 & 40 & 農業 & 11 & 3 & 2011 & 自己実現の欲求 & 60 & 40 & $\mathrm{NP}$ \\
\hline 21 & 男 & 50 & 団体役員、自営業 & 3 & 7 & 2010 & 自己実現の欲求 & 100 & 100 & $\mathrm{FC}$ \\
\hline 22 & 男 & 60 & 会社役員 & 9 & 5 & 2010 & 所属と愛情の欲求 & 80 & 60 & A \\
\hline 23 & 男 & 20 & 大学教員 & 5 & 5 & 2010 & 尊重の欲求 & 70 & 50 & $\mathrm{CP}$ \\
\hline 24 & 男 & 20 & 会社員 & 2 & 1 & 2010 & & 65 & 80 & $A C$ \\
\hline 25 & 男 & 50 & 自営業、漆作家 & 9 & 9 & 2011 & 所属と愛情の欲求 & 80 & 40 & $\mathrm{CP}$ \\
\hline 26 & 男 & 40 & 自営業 & 3 & 5 & 2010 & 自己実現の欲求 & 10 & 90 & $\mathrm{FC}$ \\
\hline 28 & 女 & 30 & 公務員 & 4 & 5 & 2011 & 所属と愛情の欲求 & 60 & 60 & $\mathrm{FC}$ \\
\hline 30 & 女 & 20 & 公務員 & 1 & 2 & 2013 & 所属と愛情の欲求 & 80 & 20 & $A C$ \\
\hline 31 & 男 & 70 & 自営業 木工業 & 4 & 1 & 2010 & 自己実現の欲求 & 50 & 50 & $\mathrm{CP}$ \\
\hline 32 & 女 & 20 & 公務員 & 4 & 2 & 2010 & 所属と愛情の欲求 & 75 & 70 & $\mathrm{NP}$ \\
\hline 33 & 男 & 40 & 自営業 & 6 & 2 & 2010 & 自己実現の欲求 & 100 & 100 & $\mathrm{FC}$ \\
\hline 36 & 男 & 30 & 公務員 & 4 & 1 & 2010 & 自己実現の欲求 & 30 & 90 & $\mathrm{NP}, \mathrm{AC}$ \\
\hline 38 & 女 & 20 & 行政(地域おこし協力隊) & 0 & 6 & 2013 & & 80 & 50 & $\mathrm{CP}$ \\
\hline 39 & 女 & 20 & 公務員 技術職 & 4 & 3 & 2010 & 所属と愛情の欲求 & 60 & 20 & $\mathrm{FC}$ \\
\hline 40 & 女 & 40 & 大学教員 & 5 & 5 & 2010 & 自己実現の欲求 & 80 & & FC \\
\hline 43 & |男 & 60 & 自営業 & 7 & 3 & 2010 & 自己実現の欲求 & 60 & 10 & $\mathrm{CP}$ \\
\hline 45 & |男 & 40 & サービス業 & 5 & 1 & 2010 & & 100 & 0 & A \\
\hline 46 & 女 & 20 & 公務員 & 1 & 1 & 2010 & 自己実現の欲求 & 70 & 50 & $\mathrm{CP}$ \\
\hline 平均 & & 37.6 & & 4.8 & 3.4 & 2010.5 & & 65.7 & 58.0 & \\
\hline 標準作 & 编差 & 15.7 & & 2.7 & 2.2 & 0.9 & & 24.5 & 29.9 & \\
\hline
\end{tabular}
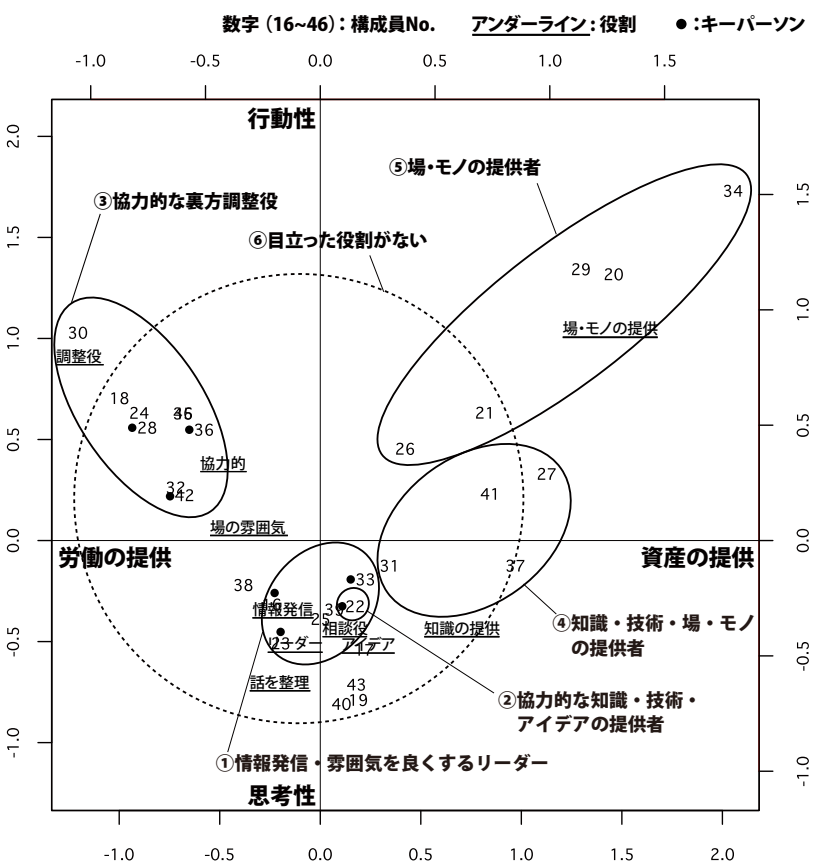

図 5 「大子町屋台研究会」の構成員・役割同時布置図

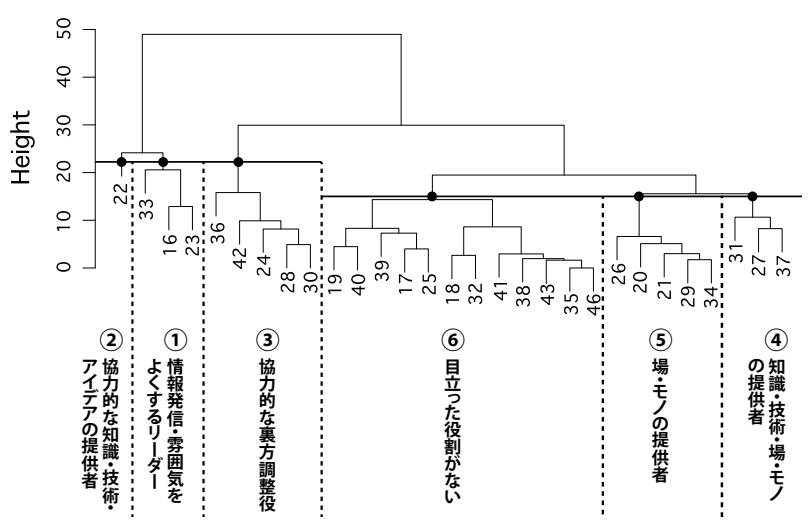

図 6 「大子町屋台研究会」の構成員のクラスター構造
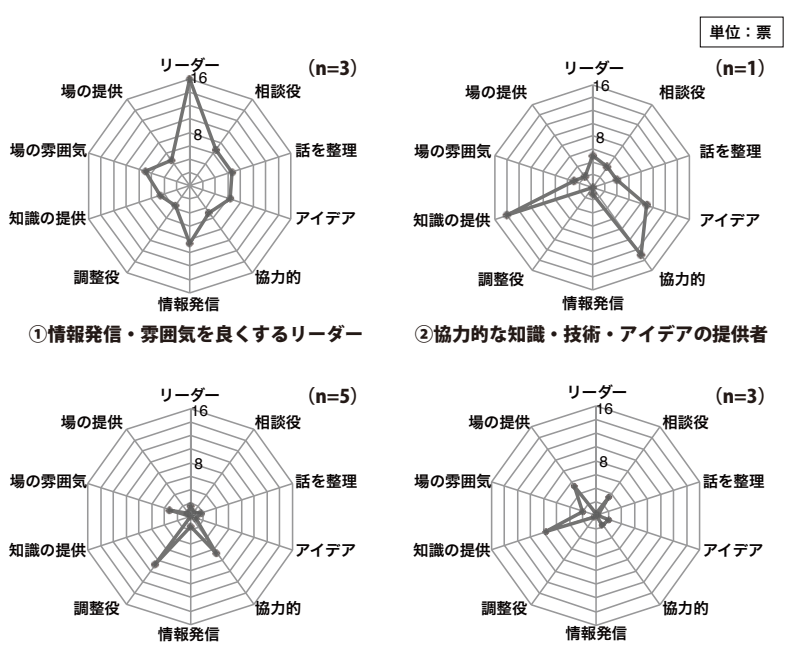

(3)協力的な裏方調整役
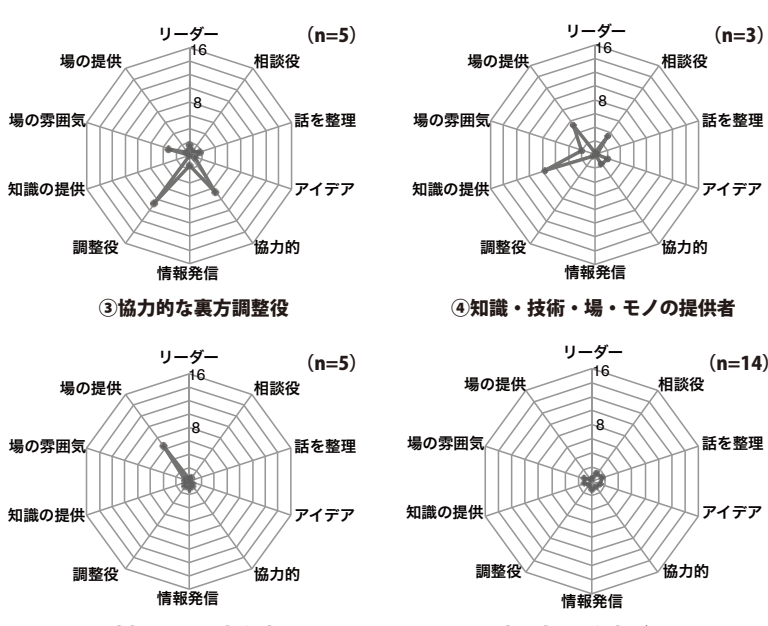

(4)知識・技術・場・モノの提供者

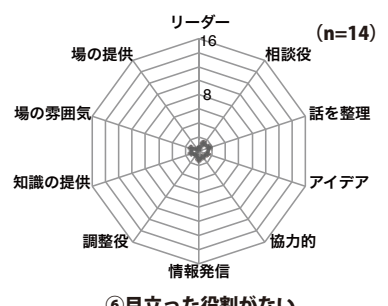

6目立った役割がない

図 7 「大子町屋台研究会」の類型別レーダーチャート
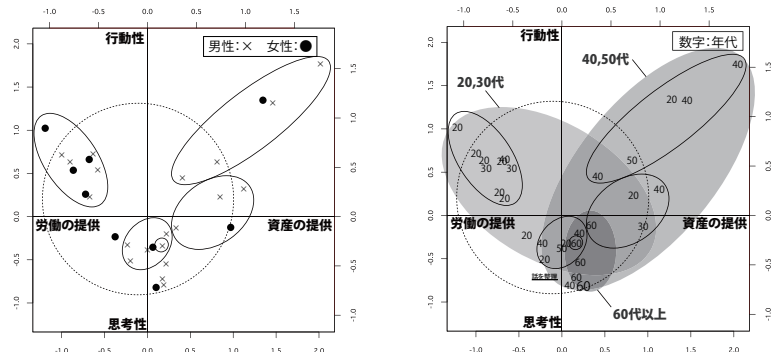

性別

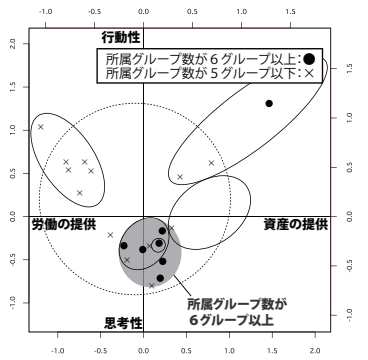

年代

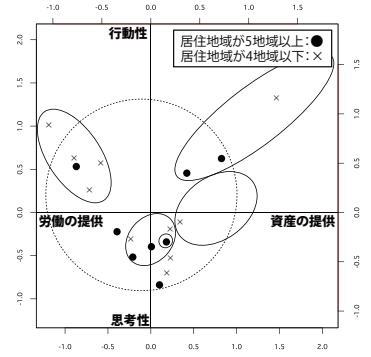

居住地域数
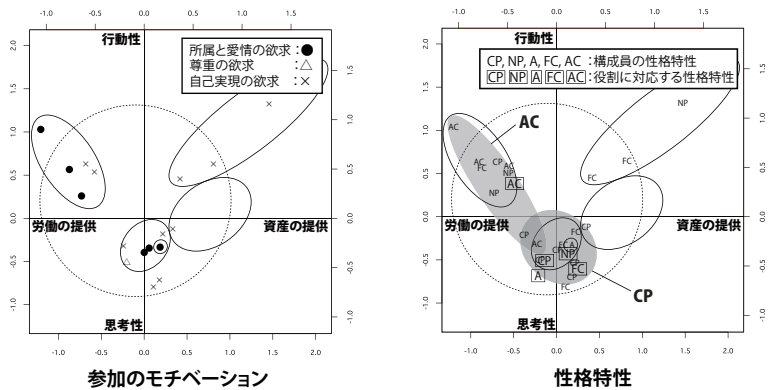

図８「大子町屋台研究会」の特性と役割の関係分析図 
(4)知識・技術・場・モノの提供者 (3 名)、(5)場・モノの提 供者（5名)、6)目立った役割がない（14名）とした。

図 5 の布置図を見ると、類型(1)は原点から少し下に位置 し、その付近に「リーダーシップを発揮している」「話を整 理したり、問題点を指摘してくれる」等の多くの役割が密 集している。これは一部の構成員が多くの役割を担ってい ることを示しており、そのことは図 7 のレーダーチャート (1)からも確認できる。類型(2についても同様のことが言え る。それに対し、類型(3、 (4)、(5)は原点から離れたところ に位置しており、類型(3)「様々な調整や裏方仕事をして くれる」「いつも協力的である」、類型(4)は「知識・技術を 提供してくれる」、類型(5は「活動のための場やものを提供 してくれる」という役割に特化して担っている。これにつ いてもレーダーチャート(3)、(4)、(5)によって確認できる。 また、類型(6に含まれる構成員はレーダーチャート(6)をみ るとほとんど役割を担っていないことが分かるが、布置図 では様々な位置にプロットされている。対局的な類型(1)と 重なるが、コレスポンデンス分析は相対的な関係性を視覚 化する手法で得票の多さは反映されないため、ほとんどの 役割を担っている構成員と担っていない構成員が近い位置 にプロットされたからである。キーパーソンについては、 類型(1)、(2、(3)に集中している。

\section{3. 構成員の特性と役割の関係}

構成員の特性を表す項目別に布置図を作成した（図 8)。 年代別にみると、20・30 代 (若者) が労働の提供と行動性 の高い役割を、40 • 50 代 (中堅者) が資産の提供と行動性 の高い役割を、60 代以上 (高齢者) が資産の提供と思考性 の高い役割を担っている。所属グループ数が 6 グループ以 上の構成員は原点に近い位置に多く集まっている。性格特 性については、CP は原点付近、特に類型(1)多く見られ、 $\mathrm{AC}$ は左側、特に類型(3に多く見られたが、その他の性格特 性に傾向は見られなかった。性別、居住地域数、参加のモ チベーションについては、役割との関係は見られなかった。

\section{4.「大子町屋台研究会」の役割構造の考察}

類型(1) 3 名全員が団体設立時から参加し、そのうち 2 名が中堅者である。多世代で構成された団体であるため、 思考性の高いリーダーシップを発揮する中堅者が若者と高 齢者をつなぎ、団体全体をまとめる役割を担っていると考 えられる。類型(2は知識・技術・アイデアを提供する材木 店経営の高齢者で、屋台を構成する木箱の制作で専門性を 発揮している。類型(3は5 名全員が若者で、そのうち4名 が行政職員である。もともと町と大学の共同プロジェクト で、若者であり、事務能力に長けているためこの役割を担 っていると推察できる。類型(4)は知識・技術・場・モノを 提供する専門性を持った中堅・高齢者、類型(5)場・モ) の提供する農家等の生産者である。目立った役割がない類 型6は活動にほとんど参加していない構成員である。類型 (1)、(2)、(3)の活躍が特に目立っているが、これは労働を提 供している構成員である。一方、自主運営を行っていく上 では資産を提供する類型(4)、(5)も重要な役割を担っている。

\section{6. 総合考察}

\section{1. 比較分析による役割分担の特徵と課題の抽出}

4. と5.の結果を用いて、図 1 と図 5 の布置図では、いず れも同じ評価軸を設定できたため、これによる比較分析が 可能である。「結いプロジェクト」は、「大町屋台研究会」 と比較するとリーダーが行動性の高い役割を担っており、 レーダーチャートからもあらゆる役割を担っていることが 分かる。そのことがリーダー以外に全体を把握している構 成員がいないという課題につながっていると推察できる。 一方、大子町屋台研究会」のリーダーは思考性の高い役割 を担っており、役割分担の偏りは「結いプロジェクト」と 比較すると小さい。これは「大子町屋台研究会」が年代に よって役割分担がされているからだと推察できる。しかし、

「結いプロジェクト」の活動は年々活発化し、まちへの貢 献度も平均 81.2 点と「大子町屋台研究会」(平均 65.7 点) と比べ高い。ここからまちに対する強い想いを持った 2 名 のリーダーが自ら行動し、多くの役割を担うことで活動を 活発化させていると推察される。ただし、団体の持続性や 次世代の担い手育成を考慮すると、リーダーの役割を分担 することも重要であると考えられる。「子町屋台研究会」 では、若者が「様々な調整や裏方仕事をしてくれる」、中堅 者が「活動のための場やものを提供してくれる」、高齢者が

「知識・技術を提供してくれる」の役割を分担しているの に対し、「結いプロジェクト」では「知識・技術を提供して くれる」を専門職に分担しているが、他はリーダーの担う ところが大きい。団体の顔としてリーダーが見世蔵の使用 依頼をしており、活動のための場やものを提供してくれる」 はリーダーが担うものだと考えると、「様々な調整や裏方仕 事をしてくれる」をうまく役割分担することが効果的であ ると考えられる。一方、「大子町屋台研究会」の普段の活動 に参加寸る構成員が限られているという課題aは「(6)目立 った役割がない」が全構成員の半数近くを占めていること から推察できる。

\section{2. 役割構造分析手法の検証}

3. と6.1. の結果を用いて、定性的分析結果で得られた各 団体の役割分担における特徵と課題が、2 団体の定量的分 析結果の比較分析から明らかにできたか検証する。3 章表 4 において「結いプロジェクト」は「大子町屋台研究会」と 比較し、2 名のリーダーへの偏りが非常に大きく(特徵 A)、 そのことが課題である（課題A）ことを示した。一方、「大 子町屋台研究会」は比較的うまく役割分担している（特徵 a）が、「結いプロジェクト」と比べ、役割を担っていない と認識されている構成員が多いという課題（課題 a）を示 した。これらは定量的分析結果により導出された 6.1.の結 果と整合性がとれた結果であり、定性的分析を通して得ら れた団体の特徵と課題を定量的に示すことができたと評価 できる。一方、2 団体共通の課題であった主体的に企画を 行う構成員がいない（課題B、b) ことに関して、定量的に 十分評価できなかったことは今後の課題である。

\section{7. まとめ}

本研究では、まちづくり団体の役割構造を解明するため 
の手法開発を目的に、(1)数理的手法を用いて 2 つままぢ くり団体の役割構造を視覚化し、(2)2 つの団体を比較分析 することによって各団体の特徵と課題を明らかにできるか 検証した。

アンケート等の調査結果を用いてコレスポンデンス分析 とクラスター分析を行い、布置図とレーダーチャートによ って 2 団体の役割構造を視覚化し、各団体の比較分析によ って役割分担の特徵と課題をある程度明らかにすることが できた。また、(1)構成員の特徵と役割分担の関係から役割 分担の要因を考察できたこと、(2)構成員の役割をく労働の 提供一資産の提供 $>$ 軸と<行動性-思考性 > 軸の 2 軸で相対 的に評価できたこと（ただし、布置図は得票の多さが反映 されないためレーダーチャートと合わせて解釈する必要が ある)、(3)レーダーチャートによって役割分担の偏りの程度 を示せたこと、(4)比較分析することで課題解決のための方 針を提示できたことも本研究の成果である。

このようにすべての構成員の役割を客観的な評価をもと に数理的手法を用いて視覚化することで、他団体との役割 構造の比較を可能とし、例えば継続的な活動を実現してい る団体の分析結果を参考にして、立ち上げて間もない団体 のマネジメントの方向性を提示寸るなどの専門家による支 援に役立てることができる。また、支援の際には団体に対 する説得力のある資料としても活用可能であると考えられ る。最後に今後の研究課題として、本研究においては対象 とした 2 団体共通の課題であった「主体的に企画を行う構 成員がいないこと」を十分評価することができず、定性的 分析結果の要点を余すことなく定量的に特定・抽出できる 手法の改良が求められる。また、本研究は特定の 2 団体を 対象として分析手法の開発を目的に検証を試みたものであ るが、今後は他の団体を対象とした調查・研究を継続的に 行い、本研究で得られた成果を精査していくとともに、研 究手法の妥当性について検証する必要がある。

\section{【謝辞】}

本調查にご協力頂きました「結いプロジェクト」と「大子町屋台研究会」の 皆さまに心より感謝申し上げます。

\section{【補注】}

（1）本研究ではまちづくりを「地域て潜在する課題の解決を目指し、地域 社会をより良くしようとする活動や取組み」と定義する。

（2）本研究では参考文献 13 の山崎の定義を参照し、(1)特定のテーマを掲 げて活動する集団であり、(2)同じ地域に居住している構成員からなり、 (3)非営利の活動を主とし、(4)まちづくりに貢献寸る活動を行っている テーマ型団体（地縁型団体は含まない）とする。

（3）川原は参考文献 4）において、「住民自治」は地方の運営はその地方の 意思によって行われるべきという概念と説明している。

（4）ネットワーク分析はさまざまな対象を点と線からなるネットワークと して表現しその構造的な特徵を探る分析手法である。

（5）饗庭らは、参考文献2）において、「生理的欲求」「安全欲求」を「久乏 欲求」「所属と愛情の欲求」「尊重の欲求」「自己実現の欲求」を「成 長欲求」とし、まちづくりや都市計画に参加している計画主体の多く は「成長欲求」のレベルの欲求に基づいているしている。

（6）「所属と愛情の欲求」の選护肢として「メンバーと一緒に活動をするの が楽しい」「メンバーが好き」「グループの居心地が良い「メンバーと 交流するのが楽しい、「尊重の欲求」の選护肢として「グループが自 分を必要としてくれる」「自分の活躍を認めてくれる」「まちづくり活 動が他者から評価される」「メディアに取り上げられる」、「自己実現の
欲求」の選护肢として「自分の成長につながる」「自分の趣味・特技が 生かせる」「まちを良くしたいり「ちの役に立ちたい」を用意した。 これらの項目は著者を含む 3 名のまちづくりの専門家によってブレイ ンストーミング法により抽出し、類似項目をまとめることで各欲求 4 項目ずつ選定した。その他の自由記术欄を選択肢に設けることで不足 項目を補った。これらの項目は今後検証寸る必要はあるが、手法開発 の初期段階においてプロトタイプとして一定の有用性を持つと考えら れる。

（7） 10 の役割項目は、必ずしもまちづくり団体におけるすべての役割を包 含しているとは限らないため今後検証する必要があるが、手法開発の 初期段階におけるプロトタイプとして一定の有用性を持つと考えられ る。

(8) 右図のよう に、表の縦列 には $11(10+1)$ の役割項目、 横列は寸べて の構成員の名 前を記載した 表による調查 票を作成し た。

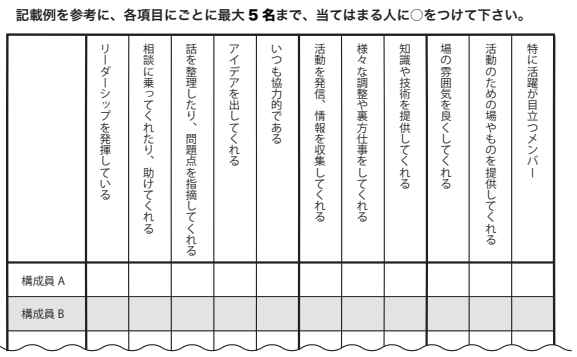

（9）この分析手法は、相対的に類似度・関倸性の強い項目は近く、弱い項 目は遠くに布置される。

（10）クラスター分析において、全体的に得票数が多い類型と少ない類型を 同じ類以度で切断寸ると少ない類型の特徵が抽出できない。今回は少 ない類型も評価する必要があったため、異なる類似度で切断した。

\section{【参考文献】}

1）総務省（2009 年）,新しいコミュニティのあり方に関する研究会報告 書

2）佐藤滋他 (2005 年), 地域協働の科学一まちの連携をマネジメントする, 成文堂

3) 山崎亮 (2012 年), コミュニティデザインの時代 自分たちで「まち」 をつる, 中公新書

4）川原晋（2006 年）,住民主体の地区まちづくりマネジメントのための 地区デザインの方法論に関する研究, 早稲田大学学位論文

5) Worth. M. J. （2009 年）, Nonprofit management-Principles and practice, SAGE Publications

6) 醍醐孝典, 保井俊之, 坂倉杏介, 前野隆司 (2016 年) , 住民参加型まちづ くりにおける楽しさ」についてーコミュニティデザインプロジェクト からの考察, 地域活性学会研究大会論文集 8, pp. 68-71

7）岸本幸子 (2007 年), まちづくりのマネージメント, まちづくり学 ア イディアから実現までのプロセス，西村幸夫 編，朝倉書店, pp. 82109

8）内閣府（2013 年）, 平成 24 年度 地域における「新しい公共」の担い 手による取組事例に関する調查報告書

9）二村敏子 (2004 年), 現代ミクロ組織論 その発展と課題, 有斐閣ブッ クス

10）川口友子 (2008 年), コミュニティにみる知識の伝垟と共有一兵庫県丹 波地域におけるガーデニングサークルを事例として-, 日本建築学会大 会学術講演梗概集, pp495-496

11）古賀菜津美他 (2014 年),グラフ理論を用いた地域コミュニティの構造 解析一過疎・高齢地域 D の人的ネットワークー, 日本建築学会大会学術 講演梗概集, pp927-928

12）島田昭仁他（2013 年）,まちづくり小集団の合意形成におけるリーダ 一的人物の機能評価に関寸る研究一桐生市における「かんのんまちづく りの会」に着目して, 日本建築学会大会学術講演梗概集, pp311-312

13）山崎亮 (2012 年), 中山間離島地域の住民参加型まちづくりにおける活 動主体の形成手法に関寸る研究 まちづくりコミュニティの形成プロ セスを例に, 東京大学学位論文

14）倉原宗孝（2002 年）, まちなか活性化・まちづくりに向けた市民主体 による事業への取り組みに関する考察帯広市「北の屋台」を通じて一, 日本建築学会技術報告集, 第 16 号, pp. 303-308

15）東京大学医学部心療内科 TEG 研究会 (2006 年), 新版 TEG II, 金子書房 